ISSN: 1858-4837; E-ISSN: 2598-019X

Volume 16, Nomor 2 (2021),

https://jurnal.uns.ac.id/region

DOI: $10.20961 /$ region.v16i2.25468

\title{
Evaluasi ketangguhan wilayah Kabupaten Wonosobo terhadap bencana pandemi Covid-19
}

\author{
The Resilience Evaluation of Wonosobo Region against the Covid-19 Pandemic
}

\author{
Z Novandaya ${ }^{1}$, H B Wijaya ${ }^{1}$, dan V Faniza ${ }^{1}$ \\ ${ }^{1}$ Center for Participatory Planning, Universitas Diponegoro, Semarang, Indonesia
}

Corresponding author's email: p5undip@yahoo.co.id

\begin{abstract}
Abstrak. Ketangguhan wilayah merupakan kemampuan masyarakat dalam menghadapi suatu kejadian bencana. Pembangunan wilayah tangguh bencana di Indonesia telah banyak dilakukan. Meski demikian ketangguhan yang telah banyak dibangun adalah ketangguhan bencana alam. Bencana non-alam pandemi Covid-19 yang mewabah di seluruh dunia mempengaruhi sistem penghidupan masyarakat baik di perkotaan maupun pedesaan. Artikel ini membahas studi kasus di Kabupaten Wonosobo, Jawa Tengah. Kabupaten Wonosobo ini termasuk ke dalam wilayah karakteristik pedesaan dengan dampak risiko Covid-19 tinggi yang berimplikasi kepada masyarakat tidak hanya dari segi kesehatan, tetapi juga dalam sosial dan ekonomi. Penelitian ini menggunakan metode analisis kualitatif deskriptif untuk mengevaluasi ketangguhan wilayah terhadap bencana pandemi Covid-19 berdasarkan empat variabel, yaitu kerawanan bencana, mitigasi, pengaturan wilayah dan adaptasi. Hasil dari penelitian ini merupakan analisis evaluatif dari ketangguhan Kabupaten Wonosobo dalam menghadapi gangguan bencana pandemi Covid-19. Dari analisis keempat variabel didapatkan hasil bahwa masih kurangnya ketangguhan wilayah yang ada di Kabupaten Wonosobo ditinjau dari aspek kerentanan, mitigasi dan adaptasi. Sedangkan pengaturan wilayah relatif memiliki modal sosial yang cukup baik untuk mendukung keberjalanan upaya meningkatkan ketangguhan wilayah lainnya. Hasil evaluasi tersebut perlu dilakukan untuk arahan rekomendasi peningkatan aspek ketangguhan wilayah yang perlu dilakukan sehingga dapat mereduksi dampak yang terjadi pada masyarakat dan aktivitas wilayah. Selain itu hasil evaluasi tersebut dapat menjadi konsep mitigasi bencana non-alam ke depannya.
\end{abstract}

Kata Kunci: Ketangguhan Wilayah; Pandemi Covid-19; Penanganan Bencana NonAlam

Received: November 21, 2018; Accepted: Januari 15, 2019; Available online: July 15, 2021

Copyright $\odot$ 2021, REGION: Jurnal Pembangunan Wilayah dan Perencanaan Partisipatif 


\begin{abstract}
The resilience of an area is the community's ability to deal with disasters. The development of disaster-resilient areas in Indonesia has been carried out a lot. However, the resilience that has been built a lot is the resilience of natural disasters. Non-natural disasters, such as the Covid-19 pandemic affects the livelihood systems of people in urban and rural areas. This article discusses a case study in Wonosobo Regency, Central Java. Wonosobo Regency is included in a rural characteristic area with a high risk of Covid-19 which has implications for the community not only in terms of health, but also in social and economic terms. This study used descriptive qualitative analysis method to realize the resilience of the Covid-19 pandemic disaster area based on four variables that is disaster vulnerability, mitigation, regional regulation, and adaptation. The results of this study will be an evaluative analysis of the resilience of Wonosobo Regency in dealing with the Covid-19 pandemic. From the analysis of the four variables, it was found that the lack of resilience of the area in Wonosobo Regency in terms of vulnerability, mitigation, and adaptation. Meanwhile, regional regulation has relatively good social capital to support ongoing efforts to increase the resilience of other areas. The results of the evaluation need to be carried out to improve the aspects of regional resilience, that need to be done so as to reduce the impact that occurs on the community and regional activities. In addition, the results of the evaluation can be a concept for future non-natural disaster mitigation.
\end{abstract}

Keywords: Covid-19 Pandemic; Non-Natural Disaster Management; Regional Resilience

\title{
1. Pendahuluan
}

Istilah "resillience" dalam Bahasa Indonesia diartikan sebagai "ketangguhan" atau "ketahanan". Kedua arti tersebut merujuk pada hal yang sama dalam praktiknya, dimana aktor yang terlibat adalah masyarakat, baik secara individu maupun komunitas, dan usaha yang dilakukan adalah membangun masyarakat yang tangguh dan memiliki ketangguhan tinggi terhadap suatu kejadian bencana. Pada konteks ketangguhan bencana, istilah ini dapat diartikan sebagai kualitas kemampuan individu atau masyarakat dalam menghadapi bencana yang menimpa [1]. Penerapan program tangguh bencana telah banyak dilakukan di Indonesia, terutama pada wilayah-wilayah dengan kerentanan tinggi terhadap bencana dan tidak memiliki cukup kapasitas untuk relokasi. Meski demikian, ketangguhan bencana yang telah banyak diterapkan sejauh ini hanya meliputi bencana alam.

Pada bulan Maret 2020, kasus penyebaran Coronavirus Disease 2019 (Covid-19) dilaporkan pertama kali masuk ke Indonesia dan masih menyebar dengan cepat ke seluruh wilayah Indonesia. Kasus Covid-19 di Indonesia hingga 5 November 2020 mencapai 425.796 kasus positif, 357.142 sembuh, dan 14.348 meninggal [2]. Pandemi Covid-19 menjadi tantangan bagi seluruh masyarakat Indonesia dimana sebelumnya belum pernah terjadi kejadian bencana non-alam. Wilayah-wilayah padat penduduk seperti Pulau Jawa menjadi konsentrasi wilayah di Indonesia, dimana wilayah dengan kepadatan tinggi memiliki tingkat penyebaran yang lebih tinggi dibandingkan dengan wilayah dengan kepadatan rendah seiring dengan tingginya 
mobilitas aktivitas masyarakat terutama di wilayah perkotaan [3]. Menurut Andersen et al. [4], penelitian lainnya juga menunjukan tingkat penyebaran di wilayah perkotaan lebih tinggi jika dibandingkan dengan wilayah pedesaan. Meski demikian, wilayah peri-urban dan pedesaan juga tidak lepas dari risiko penyebaran virus Covid-19 baik secara langsung maupun tidak langsung. Dampak dari pandemi ini tidak hanya berupa permasalahan kesehatan, tetapi juga mempengaruhi sistem sosial dan ekonomi sehingga kemampuan setiap wilayah untuk bertahan menjadi hal yang penting dalam membangun wilayah tangguh bencana.

Sistem utama dalam pembangunan ketangguhan masyarakat di suatu wilayah adalah bagaimana cara mengurangi kerugian dan risiko, serta kemampuan pemulihan dalam jangka waktu cepat [5]. Ketangguhan masyarakat juga mencakup kesadaran, adaptasi, dan partisipasi [6] dimana dalam hal ini membutuhkan kerjasama dari setiap individu. Wilayah peri-urban dan pedesaan identik dengan karakteristik partisipasi yang tinggi dalam kegiatan sosial kemasyarakatan. Partisipasi masyarakat merupakan sesuatu yang baik dalam memperkuat ketangguhan bencana alam. Namun pada kasus bencana pandemi Covid-19, kegiatan yang melibatkan perkumpulan banyak orang di satu tempat justru akan menjadi masalah. Hal ini menunjukan salah satu perbedaan yang signifikan antara studi ketangguhan bencana alam dengan ketangguhan bencana non-alam.

Studi kasus pada artikel ini terkonsentrasi pada salah satu wilayah di Jawa Tengah yaitu Kabupaten Wonosobo, dimana wilayah ini tercatat sebagai wilayah dengan risiko sedang pada kasus penyebaran virus Covid-19 di Indonesia. Berdasarkan laporan perkembangan kasus perNovember 2020, jumlah kasus yang ada di Wonosobo mencapai 2.125 kasus positif dengan 1.182 sembuh dan 112 meninggal [7]. Angka ini menjadi 5 besar angka tertinggi kasus Covid19 di Jawa Tengah yang secara total mancapai 38.227 dengan klaster jumlah tertinggi adalah Kota Semarang yaitu 10.553 yang berdampak pada tingginya pula kawasan sekitarnya seperti Kabupaten Demak dan Kabupaten Kendal.

Kabupaten Wonosobo menjadi kabupaten tertinggi untuk jumlah kasus terkonfirmasi di luar kawasan Kota Semarang dan sekitarnya (Kabupaten Demak dan Kabupaten Kendal). Tingginya angka kasus dan upaya dalam pencegahan penyebaran virus Covid-19 mempengaruhi kehidupan masyarakat. Tujuan dari studi kasus ini adalah untuk mengevaluasi ketangguhan wilayah Kabupaten Wonosobo terhadap bencana pandemi Covid-19 guna mengetahui sejauh mana tingkat ketangguhan dan kemampuan masyarakat dalam menyelesaikan permasalahan yang merupakan dampak tidak langsung.

\section{Metode}

Metode penelitian yang dilakukan pada studi ini adalah dengan menggunakan pendekatan analisis kualitatif deskriptif. Hal ini dilakukan untuk mengelaborasi antar data dengan analisis kualitatif berdasarkan dengan variabel ketangguhan wilayah. Pada penelitian ini, variabel ketangguhan wilayah merupakan penyesuaian terhadap variabel dalam pembangunan kota 
tangguh bencana. Penyesuaian tersebut dibatasi pada analisis kerawanan, mitigasi, pengaturan wilayah, dan adaptasi yang dapat dilihat pada Gambar 1.

Data sekunder pada penelitian ini merujuk kepada kajian indeks kinerja utama Kabupaten Wonosobo 2020 yang merupakan ukuran capaian output maupun outcome dari kinerja pemerintah daerah. Secara umum, kajian indeks kinerja utama ini mengidentifikasi kinerja pemerintah daerah dari indikator demokrasi, gotong royong, rasa aman, dan toleransi. Namun, yang digunakan pada penelitian ini mengacu kepada dua indeks utama, yaitu indeks rasa aman dan indeks gotong royong. Pada indeks rasa aman digunakan untuk mengidentifikasi kerawanan melalui indikator kerentanan bencana, sedangkan kesiapsiagaan bencana digunakan untuk analisis pada mitigasi secara struktural. Sedangkan secara nonstruktural menggunakan analisis modal sosial pada indeks gotong royong dengan indikator partisipasi masyarakat dalam pertemuan/sosialisasi, ketersediaan membantu tetangga dan kemudahan mendapat pertolongan keuangan. Pada indeks gotong royong digunakan untuk menganalisis indikator penelitian mitigasi bencana, pengaturan wilayah dan adaptasi.

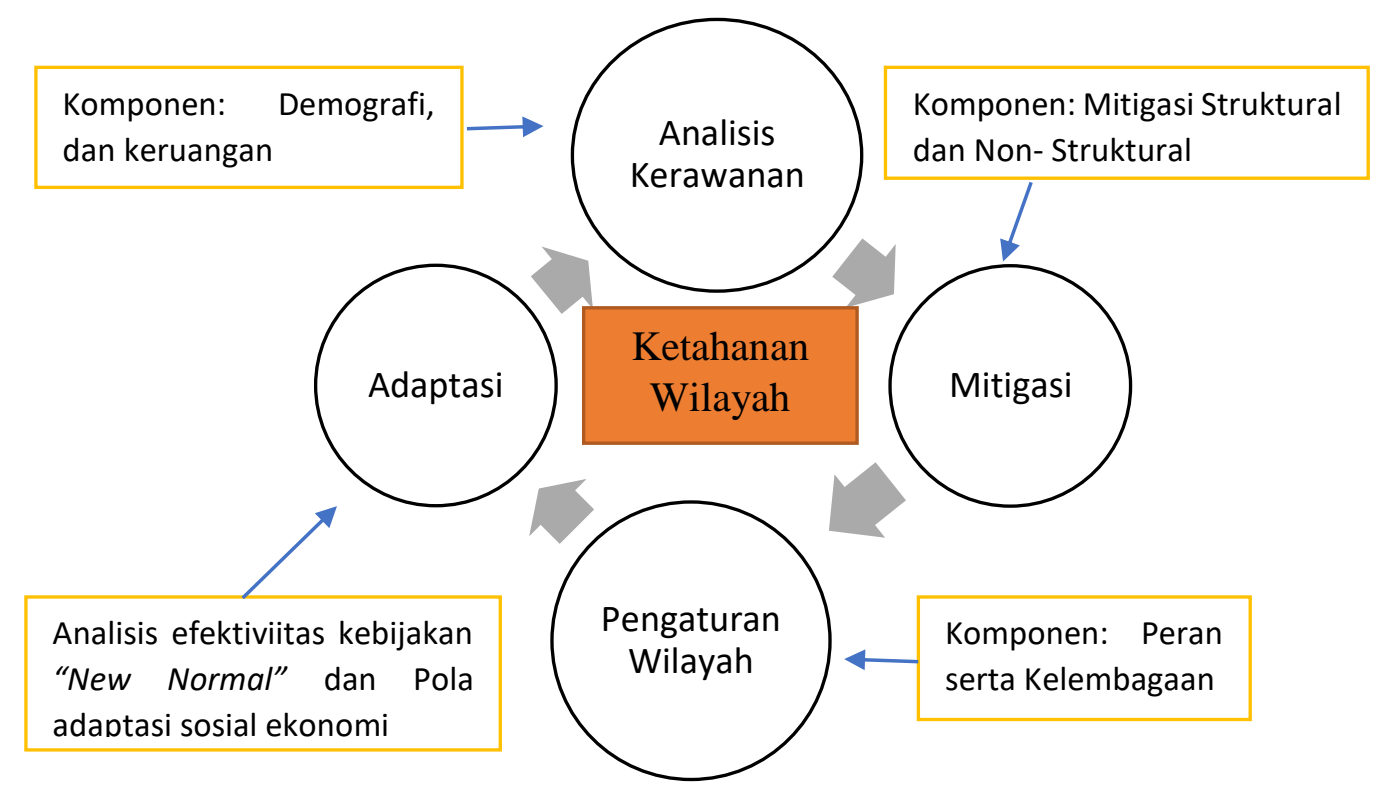

Gambar 1. Kerangka Penelitian Ketangguhan Wilayah pada Bencana Pandemi Covid-19 [8].

Evaluasi yang dilakukan berdasarkan empat variabel tersebut, dengan analisis utama adalah pada variabel kerawanan akan dianalisis kondisi persebaran Covid-19 yang akan dikaitkan dengan hotspot kawasan, kepadatan penduduk dan kerentanan karakteristik penduduk. Data pada variabel ini merupakan data sekunder dari Dinas Kesehatan, Dinas Kependudukan, kajian indeks kinerja utama Kabupaten Wonosobo 2020 dan untuk spasial dari Bappeda Litbang Kabupaten Wonosobo. Variabel mitigasi akan dibahas mengenai upaya struktural maupun non-struktural yang dilakukan untuk mencegah atau mereduksi persebaran kasus Covid-19. 
Pada struktural dilakukan analisis persebaran rumah sakit rujukan, dan ruang isolasi Covid-19 yang telah tersedia. Pada non-struktural dilakukan berdasarkan program sosialisasi yang dilaksanakan untuk Covid-19, selain itu modal sosial masyarakat yaitu untuk mereduksi kemungkinan partisipasi masyarakat dan kepedulian antar masyarakat juga perlu dianalisis dalam upaya memitigasi persebaran bencana pandemi Covid-19 secara merata. Data ini didapatkan dari data sekunder, yaitu berdasarkan data analisis indeks kinerja utama Kabupaten Wonosobo 2020.

Pada variabel pengaturan wilayah dilakukan analisis berdasarkan peran serta kelembagaan. Pada peran kelembagaan dianalisis baik partisipasi pemerintah, keaktifan swasta dan partisipasi masyarakat dalam penanganan Covid-19. Sedangkan dari sisi analisis ekonomi, yang dilakukan adalah untuk mengetahui pola perubahan sektor ekonomi dan aktivitasnya. Data pada variabel pengaturan kewilayahan didapatkan dari data sekunder kajian indeks kinerja utama Kabupaten Wonosobo 2020. Analisis ketangguhan berdasarkan adaptasi yang dilakukan analisis dilakukan dengan menggunakan data sekunder hasil kajian profil masyarakat di era new normal dari BPS terkait pola kebiasaan baru masyarakat Wonosobo di era pandemi. Dari keempat analisis tersebut akan diketahui ketangguhan wilayah yang ada di Kabupaten Wonosobo dan dapat ditarik rekomendasi kedepannya untuk peningkatan ketangguhan wilayah.

\section{Hasil penelitian dan pembahasan}

Pada pembahasan akan dijelaskan kondisi ketangguhan wilayah berdasarkan framework yang telah dibuat sebagai evaluasi penanganan ke depannya. Aspek kerentanan diperlukan untuk pemetaan spasial kondisi bahaya yang timbul dari suatu gangguan serta mengidentifikasi kondisi sosial ekonomi wilayah [8]. Untuk penelitian ketangguhan wilayah pada bencana pandemi Covid-19 ini akan dipetakan kondisi sebaran kasus Covid-19 yang terjadi hingga tanggal 5 November 2020 yang di-overlay dengan data kondisi eksisting hotspot penyebaran Covid-19 dan kepadatan penduduk. Data kasus Covid-19, hotspot dan kepadatan penduduk ini dapat mengidentifikasi risiko bahaya yang terjadi dari suatu wilayah kecamatan. 


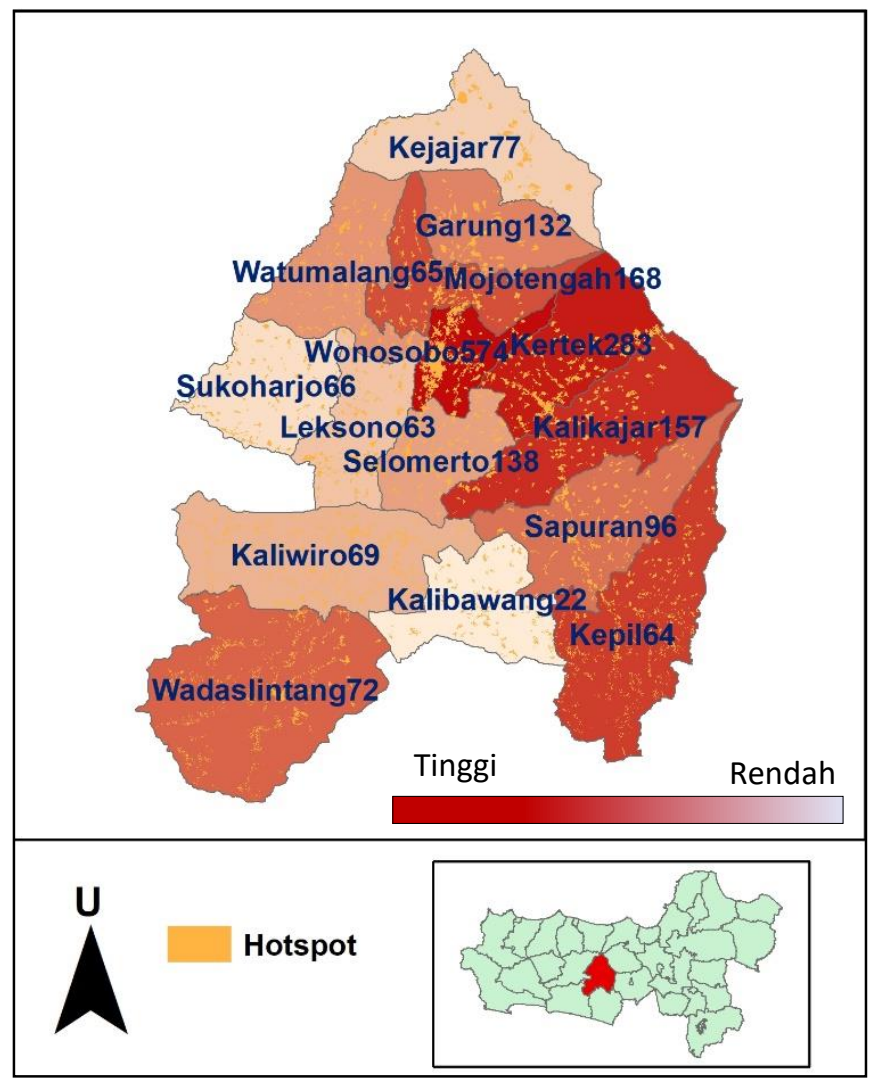

Gambar 2. Peta kerentanan spasial wilayah [7].

Berdasarkan peta spasial tersebut dapat diketahui bahwa jumlah penduduk yang relatif tinggi yang terinterpretasi berdasarkan gradasi warna peta dan semakin masihnya titik hotspot (permukiman penduduk, industri, dan objek wisata) maka memiliki kecenderungan jumlah kasus Covid-19 yang tinggi pula. Hal ini terjadi karena pada lokasi hotspot dan jumlah penduduk mempercepat terjadinya penularan Covid-19. Peta pada Gambar 2 tersebut diketahui bahwa Kecamatan Wonosobo, Kertek, dan Kalijajar merupakan pusat penyebaran Covid-19 yang ada di Wonosobo. Hal ini terjadi karena ketiga lokasi tersebut merupakan pusat aktivitas pemerintahan dan ekonomi sehingga mobilitas dan hetroginitas penduduk yang ada sangat tinggi. Selain itu, ketiga kecamatan tersebut terjadi masif Covid-19 dari klaster industri, perkantoran yang berakibat ke klaster rumah tangga dan terdapat pula penularan dari luar akibat aktivitas pergerakan masyarakatnya. 


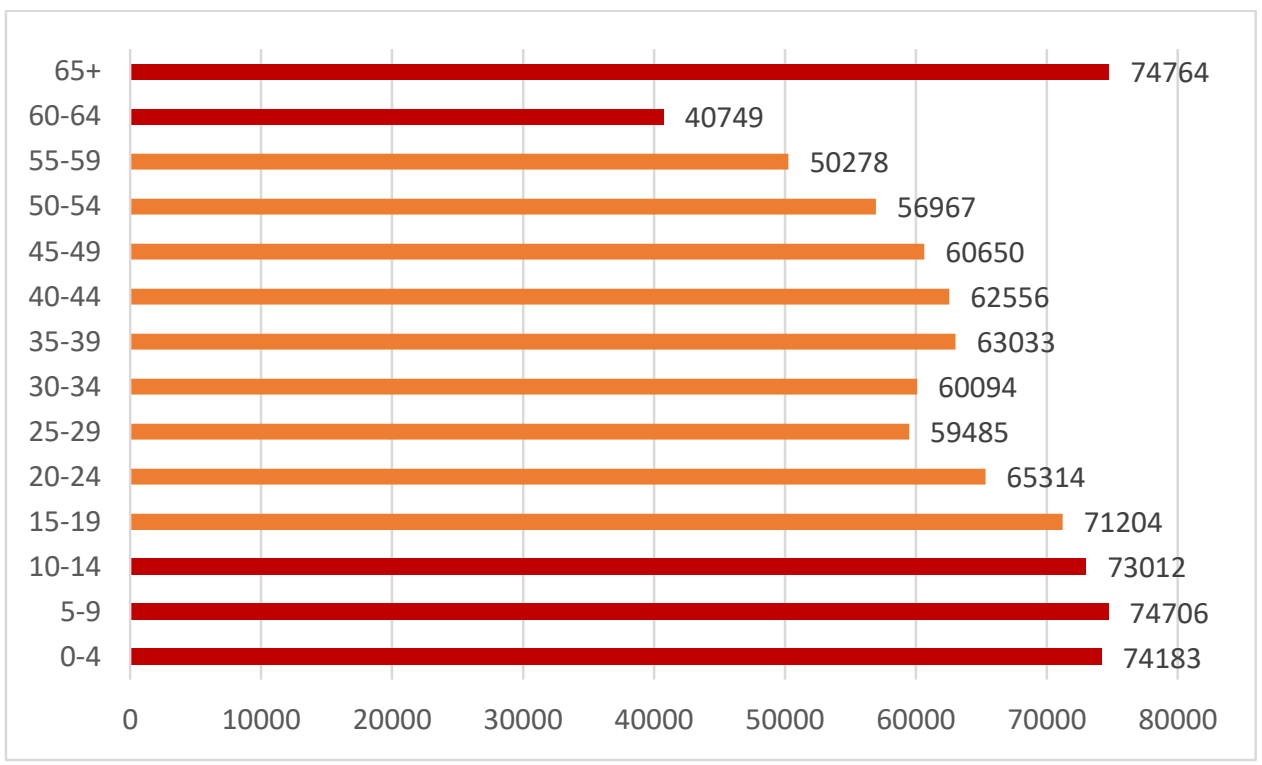

Gambar 3. Karakteristik kelompok umur penduduk [9].

Selain diidentifikasi kerentanan secara fisik, perlu dianalisis pula kerentanan secara karakteristik penduduk. Dari sisi kelompok umur, berdasarkan data dari Dinas Kependudukan Kabupaten Wonosobo (Gambar 3) dapat diketahui bahwa secara karakter penduduk Kabupaten Wonosobo yang berada di kelompok usia rentan, yaitu 0-14 tahun dan di atas 60 tahun memiliki jumlah yang relatif tinggi bahkan mendominasi. Hal ini dapat berbahaya secara ketangguhan wilayah dari sisi karakteristik kependudukan, karena rawan untuk memiliki gejala akut dampak dari penularan Covid-19. Selain itu berdasarkan kajian dari BPS tentang Kenormalan Baru Masyarakat [10], Kabupaten Wonosobo terjadi penurunan pendapatan hingga Bulan Juni 2020 yaitu sebesar 60,39\% dan sektor paling terdampak yaitu sektor perdagangan dan jasa yang menurun hingga $80,3 \%$. Padahal secara karakteristik penduduk kedua sektor tersebut adalah penyumbang tenaga kerja yang relatif tinggi.

Berdasarkan analisis kerentanan yang terjadi dapat diketahui bahwa secara karakter fisik kawasan perkotaan (sekitar Kecamatan Wonosobo) perlu perhatian khusus dalam penanganan Covid-19 karena terjadi pengklasteran kasus Covid-19 terkonfirmasi terutama di daerah-daerah hotspot, seperti rumah tangga, pasar, industri, perkantoran dan tempattempat wisata. Sedangkan secara karakteritik sosial ekonomi, perlu adanya perhatian di kelompok umur rentan karena jumlah yang ada tinggi dan perlunya penanganan pemulihan ekonomi khususnya di sektor perdagangan dan jasa. Hal ini dilakukan untuk memperkuat ketangguhan wilayah Kabupaten Wonosobo.

Secara mitigasi beberapa program telah dilakukan dalam upaya ketangguhan wilayah. Upaya mitigasi ini dibedakan menjadi mitigasi struktural (kondisi infrastruktur fisik) dan nonstruktural (non-fisik). Berdasarkan kondisi non-struktural diidentifikasi hasil kajian IKU 
Wonosobo indeks Gotong Royong yang mengidentifikasi modal sosial yang ada di masyarakat, yaitu partisipasi masyarakat dalam pertemuan/sosialisasi, ketersediaan membantu tetangga dan kemudahan mendapat pertolongan keuangan. Ketiga indikator tersebut diperlukan untuk menganalisis kekuatan internal yang ada di masyarakat sehingga dapat meningkatkan ketangguhan masyarakat dari Covid-19. Berdasarkan data keberadaan partisipasi masyarakat dalam pertemuan cenderung "berpartisipasi aktif", ketersediaan membantu tetangga sangat bersedia cenderung "sangat bersedia" dan kemudahan mendapat pertolongan keuangan relatif "mudah". Dari data tersebut dapat diintepretasikan bahwa modal sosial dari masyarakat kuat sehingga dapat menjadi modal mitigasi non-struktural yang dilakukan, seperti sosialisasi, tracking kasus dan penerapan adaptasi nantinya.

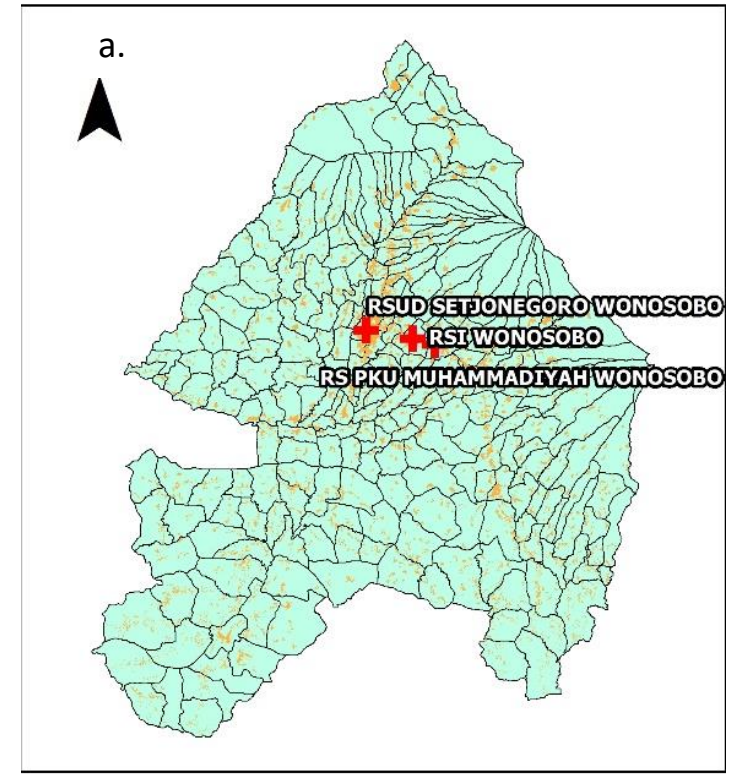

Rumah Sakit

Rujukan Covid 19

Hotspot

Gambar 4. Sebaran Rumah Sakit Rujukan Covid-19 [11].

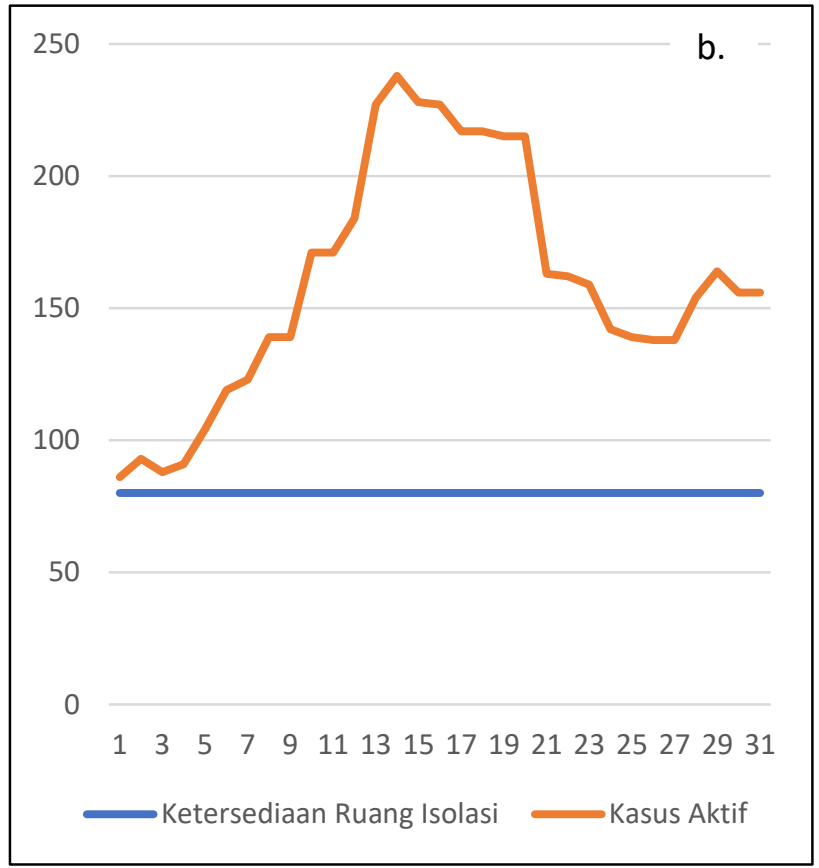

Gambar 5. Perbandingan Jumlah Ketersediaan Ruang Isolasi dan Kasus Aktif [11].

Secara struktural mitigasi bencana non alam Covid-19 ini dapat dievaluasi ketangguhannya berdasarkan sebaran lokasi rumah sakit rujukan Covid-19, dan jumlah ruang isolasi dibandingkan dengan kasus aktif. Berdasarkan data pada Gambar 4, rumah sakit rujukan sekitar perkotaan Wonosobo yaitu Kecamatan Wonosobo dan Kecamatan Kertek. Hal ini mengindikasikan bahwa secara jangkauan masih jauh dan belum tersebar sehingga apabila terjadi kasus Covid-19 yang berdampak pada gangguan pernafasan akut dan membutuhkan pertolongan segera akan berbahaya bagi jiwa pesien tersebut. Selain itu, berdasarkan data ketersediaan ruang isolasai (Gambar 5) hanya 80 tempat tidur, apabila dibandingkan dengan jumlah kasus aktif dalam rentang 28 Agustus-25 September 2020 terlihat bahwa ruang isolasi 
hanya dapat mengatasi rata-rata $49,9 \%$ pasien terkonfirmasi aktif. Bahkan pada puncak kasus aktif, ketersediaan ruang isolasi hanya menampung $33,67 \%$.

Hal ini mengindikasikan bahwa pasien terkonfirmasi Covid-19 lebih dari 50\% akan isolasi mandiri di rumah. Secara mitigasi penularan, isolasi mandiri cenderung berisiko terhadap kerentanan khususnya pada klaster rumah tangga dan transmisi lokal. Peningkatan jumlah ruang isolasi secara jumlah dan sebaran lokasinya perlu dilakukan dalam upaya mitigasi, khususnya untuk mereduksi masifnya penyebaran yang terjadi, untuk memperkuat ketangguhan wilayah dari bencana non alam (Covid-19). Penentuan ruang isolasi dapat berdasarkan analisis kerawanan sebelumnya, yaitu berdasarkan titik hotspot penularan, jumlah bahaya gangguan yang terjadi dan karakteristik penduduk, sehingga penyediaannya dapat efektif.

Pada upaya ketangguhan wilayah, pengaturan wilayah dalam tata kelola sangat penting dilakukan, menurut Jabareen [8] untuk mewujudkan kota yang tangguh perlu adanya keputusan yang inklusif dalam ranah perencaaan, keterbukaan diskusi, akuntabilitas dan kolaborasi. Hal ini juga penting untuk mewujudkan ketangguhan wilayah pada masa pandemi Covid-19, perlu adanya inklusifitas dalam keputusan, yaitu kolaborasi masyarakat, lembaga non-profit, swasta dan pemerintah dalam penanganan.

Pada penanganan pandemi Covid-19, pemerintahlah yang memiliki peran sentral dalam penanganannya. Peran pemerintah ini dilakukan secara hierarkis dari tingkat pemerintah pusat hingga daerah. Untuk pemerintah pusat memiliki peran sebagai koordinator dan pengambil keputusan pada penanganan pemulihan ekonomi dan kesehatan. Sedangkan, pemerintah daerah juga terlibat dalam pencegahan dan edukasi ke masyarakat serta bantuan sosial apabila dibutuhkan tambahan. Pemerintah Daerah Wonosobo juga melakukan hal serupa, yaitu sosialisasi, tracking kasus dengan tim gugus tugas, penyediaan ruang isolasi, penjagaan keamanan lingkungan dan kebijakan lain terkait pembatasan aktivitas masyarakat.

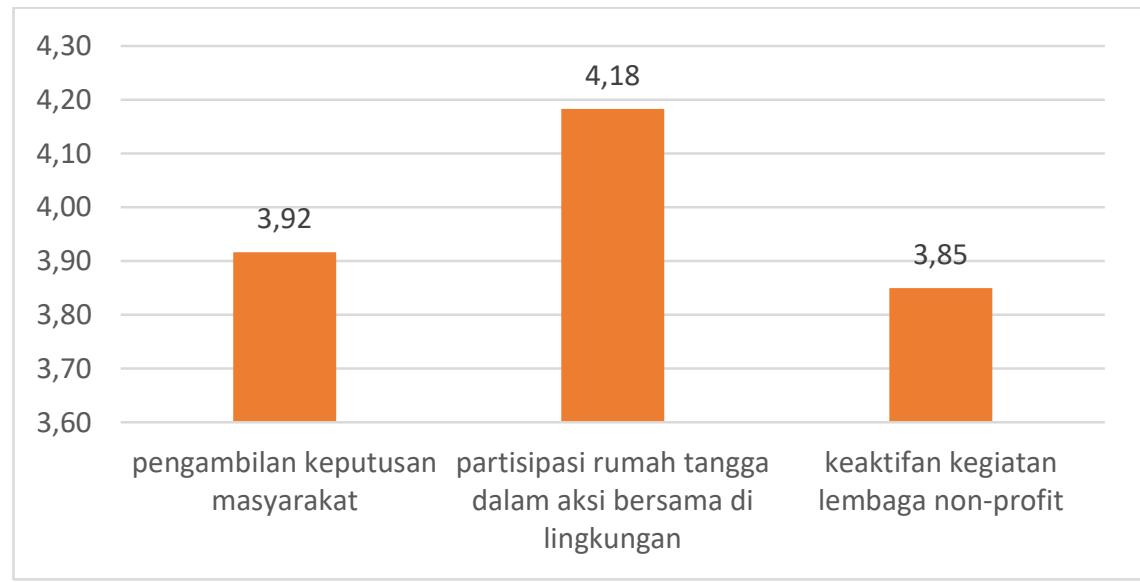

Gambar 6. Partisipasi masyarakat dan lembaga non-profit [11]. 
Peran sentral dari pemerintah tersebut juga didukung dengan kolaborasi yang ada dengan masyarakat. Berdasarkan kajian Indeks Kinerja Pemerintah [11] pada Indeks Gotong Royong dan Rasa Aman dapat diidentifikasi bahwa keterlibatan pengambilan keputusan masyarakat memiliki nilai rata-rata 3,92 atau cenderung aktif, pada partisipasi rumah tangga dalam aksi bersama di lingkungan juga memiliki nilai rata-rata 4,18 atau cenderung atif. Sedangkan dari keaktifan kegiatan lembaga non-profit sesuai permasalahan juga berpartisipasi aktif. Keaktifan masyarakat dan lembaga non-profit tersebut dapat menjadikan kekuatan dalam ketahanan wilayah khususnya pada penanganan Covid-19 yang ada di Kabupaten Wonosobo (Gambar 6).

Pada tahap akhir yang menentukan ketahanan wilayah adalah adaptasi masyarakat dalam bencana pandemi Covid-19 ini. Adaptasi kebiasaan baru atau sering disebut "new normal" ini memiliki beberapa adaptasi baru yang terjadi, yaitu memakai masker, mencuci tangan, menjaga jarak, dan mengurangi aktivitas di luar rumah dengan bekerja dari rumah dan belanja online. Kebiasaan baru tersebut tercipta dari karakteristik penyebaran Covid-19 yang cepat antar manusia. Implementasi dari kebiasaan baru ini perlu dievaluasi efektifitas pelaksanaannya.

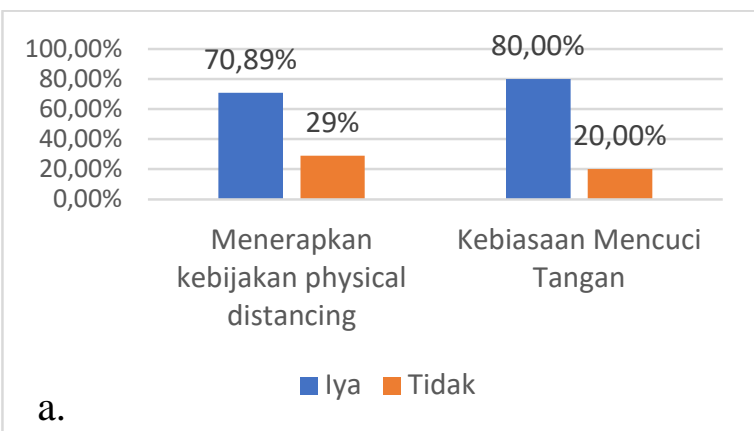

Gambar 7. Adaptasi sosial masyarakat [10].

Berdasarkan data (Gambar 7) yang bersumber dari Kajian Kenormalan Baru [10] menerapan physical distancing atau jaga jarak hanya dilakukan oleh $70,89 \%$ responden penelitian, sedangkan kebiasaan mencuci tangan dilakukan $80 \%$ responden penelitian. Pada penggunaan masker masih didominasi pada tidak pernah/jarang sekali pakai masker. Dari ketiga indikator pengukuran tersebut maka masih kurangnya kesadaran masyarakat untuk dapat membiasakan diri beradaptasi untuk mereduksi kasus penyebaran kasus Covid-19 yang ada. Selain itu dari sisi adaptasi pola aktivitas ekonomi, terdapat beberapa perubahan yang terjadi, yaitu kebiasaan untuk bekerja dari rumah hanya dapat dilakukan oleh $12,53 \%$ responden, $36,96 \%$ bekerja dari rumah temporal, yang masih harus masuk kantor/kerja dan pekerjaan tidak memungkinkan bekerja dari rumah adalah 50,51\%. Dominasi angka harus masuk kantor dan pekerjaan tidak memungkinkan bekerja karena sektor dominasi pekerja adalah sektor informal dan buruh sehingga tidak memungkinkan untuk bekerja dari rumah. Sedangkan kebisaan untuk belanja online di Kabupaten Wonosobo juga meningkat khususnya pada kelompok umur 26-39 tahun. 
Berdasarkan analisis kebiasaan baru tersebut, dapat diketahui bahwa masih perlunya sosialisasi dan pengawasan pada kebiasaan baru di masyarakat. Hal ini penting dilakukan apalagi 50\% lebih masyarkat tidak memungkinkan untuk bekerja dari rumah, sehingga perlu penerapan kebiasaan baru yang lebih ketat. Sosialisasi dan pengawasan dapat dilakukan dengan memberdayakan tokoh agama atau masyarakat karena menurut Kajian IKU Wonosobo [11], tingkat kepercayaan dengan tokoh agama atau masyarakat cenderung lebih tinggi daripada pemerintah saja yang melakukan sosialisasi dan pengawasan.

\section{Kesimpulan}

Berdasarkan penelitian ini, dapat disimpulkan bahwa ketahanan wilayah dari bencana nonalam (Covid-19) dapat diidentifikasi dan dievaluasi berdasarkan kerentanan yang ada, mitigasi yang sudah dilakukan, pengaturan wilayah yang dilakukan dan adaptasi sosial ekonomi masyarakat. Pada kerentanan Kabupaten Wonosobo merupakan daerah dengan salah satu jumlah kasus terkonfirmasi positif terbanyak di Jawa Tengah dengan karakteristik dominasi pedesaan dan relatif jauh dari daerah perkotaan. Kerentanan secara spasial dapat diketahui sebaran lokasi kasus terkonfirmasi selaras dengan sebaran penduduk, dan hotspot kasus Covid-19 yang ada di Kabupaten Wonosobo. Sedangkan secara karakteristik penduduk dan ekonomi, kerawanan yang ada di Kabupaten Wonosobo relatif tinggi karena dominasi penduduk usia rentan sangat tinggi dan terjadi penurunan signifikan pendapatan pada kegiatan perekonomian mayoritas, yaitu pardagangan dan jasa.

Pada mitigasi dibagi menjadi mitigasi struktural dan non-struktural. Pada mitigasi struktural kondisi ketahanan wilayah yang dievaluasi berdasarkan jumlah rumah sakit rujukan dan jumlah kamar isolasinya dapat diketahui masih kurang secara jangkauan maupun sebaran. Hal ini dikarenakan hanya terdapat tiga lokasi rumah sakit rujukan dan terkonsentrasi pada Kecamatan Kertek dan Kecamatan Wonosobo. Sedangkan dari jumlah ruang isolasi, hanya mampu menampung kurang dari 50\% kasus aktif Covid-19. Secara mitigasi non-struktural serta variabel pengaturan wilayah, telah terdapat modal sosial yang baik untuk memitigasi bencana pandemi Covid-19 dan pengelolaan keputusan yang inklusif.

Pada adaptasi kebiasaan baru masih perlu ditingkatkan, hal ini dikarenakan masih kurangnya partisipasi masyarakat dalam penerapan jaga jarak, mencuci tangan dan memakai masker. Bahkan pada indikator memakai masker 53,97\% masih jarang/tidak memakai masker. Selain itu, dari pola aktivitas yang ada masyarakat masih ketergantungan untuk aktivitas di luar rumah karena dominasi pekerjaan tidak memungkinkan bekerja dari rumah seperti khususnya perdagangan dan jasa.

Berdasarkan penelitian ini, maka dapat diberikan saran dan rekomendasi dari hasil evaluasi ketahanan wilayah dari bencana non-alam (Covid-19) sebagai berikut.

- Perlu kebijakan perlindungan di daerah yang memiliki kerawanan tinggi baik secara spasial maupun karakteristik. 
- Perlunya kebijakan pemulihan ekonomi daerah khususnya bidang perdagangan dan jasa.

- Perlu ditambahkan ruang isolasi baik secara sebaran spasial maupun jumlahnya dengan berdasarkan analisis kerawanan.

- Perlunya peningkatan kesadaran masyarakat tentang kebisaan baru, untuk efektifitas dapat melibatkan tokoh agama atau tokoh masyarakat setempat.

- Perlunya pembiasaan penggunaan media digital untuk melakukan pola aktivitas ekonomi masyarakat.

\section{Ucapan Terima Kasih}

Artikel ini menggunakan data berdasarkan Kajian Indeks Kinerja Utama Kabupaten Wonosobo tahun 2020 yang merupakan kajian kerjasama antara P5 Universitas Diponegoro dengan Pemerintah Daerah Kabupaten Wonosobo.

\section{Referensi}

[1] Connor KM, Davidson JRT. Development of a new Resilience scale: The Connor-Davidson Resilience scale (CD-RISC). Depress Anxiety 2003;18:76-82. https://doi.org/10.1002/da.10113.

[2] Komite Penanganan Covid-19 dan Pemulihan Ekonomi Nasional (KPC PEN). Data Covid 19 Indonesia 2020.

[3] Paul R, Arif AA, Adeyemi O, Ghosh S, Han D. Progression of COVID-19 From Urban to Rural Areas in the United States: A Spatiotemporal Analysis of Prevalence Rates. J Rural Heal 2020;36:591-601. https://doi.org/10.1111/jrh.12486.

[4] Andersen LM, Harden SR, Sugg MM, Runkle JD, Lundquist TE. Analyzing the spatial determinants of local Covid-19 transmission in the United States. Sci Total Environ 2021;754:1-10. https://doi.org/10.1016/j.scitotenv.2020.142396.

[5] Bruneau M, Chang SE, Eguchi RT, Lee GC, O'Rourke TD, Reinhorn AM, et al. A Framework to Quantitatively Assess and Enhance the Seismic Resilience of Communities. Earthq Spectra 2003;19:733-52. https://doi.org/10.1193/1.1623497.

[6] Faniza V. Sustainability of Urban Coastal Area Based on Socio-Ecological System (The Case of Tugu District, Semarang City). Universitas Diponegoro, 2019.

[7] Pusat Informasi Covid-19. Data Covid-19 Kabupaten Wonosobo 2020.

[8] Jabareen Y. Planning the resilient city: Concepts and strategies for coping with climate change and environmental risk. Cities 2013;31:220-9. https://doi.org/10.1016/j.cities.2012.05.004.

[9] Dinas Kependudukan Kabupaten Wonosobo. Data Penduduk Kabupaten Wonosobo. 2020.

[10] Badan Pusat Statistik. Kajian Kenormalan Baru Kabupaten Wonosobo. 2020.

[11] P5 Undip. Kajian Indeks Kinerja Utama Kabupaten Wonosobo. Semarang: Pusat Pelayananan Perencanaan Pembangunan Partisipatif (P5) Universitas Diponegoro; 2020. 